\title{
Analysis of Latvian E-government Effectiveness
}

\author{
Daiga Dumpe, Latvia University of Agriculture, Irina Arhipova, Latvia University of Agriculture
}

\begin{abstract}
This research focuses on e-government development index. To raise the index in Latvia, factors influencing the index value were studied and recommendations for increasing the egovernment development index are offered.The influencing factors significance of e-government development index and the impact of these factors were studied and analyzed.
\end{abstract}

Keywords -e-government, electronic government readiness index

\section{INTRODUCTION}

Electronic government or e-government means IT integration and application in more effective and modern operating in state, local government and related companies, as well as creating links between people and organizations [1], [2].

E-government is the way how state and local government can use new technologies to their advantage to provide citizens and businesses easier access to information and services, improve their service quality and create more opportunities to participate in government work.

To better reflect the e-government development around the world, focusing on how governments use the web sites and web portals, as well as to provide public services and increase opportunities for citizens to participate in decision-making, has generated the data necessary to calculate the e-government development index. The United Nations e-government development index (EGDI) is a comprehensive scoring of the willingness and capacity of national administrations to use online and mobile technology in the execution of government functions [3].The e-government development index is not designed to capture e-government development in an absolute sense. Rather, the index rates the performance of national governments relative to one another. The maximum possible value is one and the minimum is zero. Mathematically, the EGDI is a weighted average of three normalized scores on the most important dimensions of e-government, namely: scope and quality of online services, telecommunication connectivity, and human capacity. Each of these sets of indexes is itself a composite measure that can be extracted and analyzed independently.

The aim of the paper is to assess the Latvian e-government readiness and offer detailed recommendations for egovernment development index increases.

To achieve the aim following tasks are defined:

a) to analyze e-government development index;

b) to examine factors affecting the relevance of egovernment development index increases according to the country;

c) to assess the influence of the proportion of egovernment development index increase the Latvian case.

\section{MATERIALS AND METHODS}

EGDI data were collected for 173 countries. To sort the states by EGDI was used cluster analysis. The resulting output data were chosen to split in three, four, five and six clusters. In cluster analysis the analyzed objects are classified in a way that each object on the set features would be similar to other cluster sites. Thus, it is up to so-called cluster groups, which combines the initial parameters defined, homogeneous or related items[4]. Dividing data in six clusters results in some of the clusters having a small number of observations (Fig. 1.).

Also, the distribution of five and four clusters is not optimal because the distribution includes a small number of observations in several clusters. To determine which cluster quantities can be regarded as optimal, conclusive meaning has the parameter that describes the distance between two clusters, which are defined on the chosen distance measure.
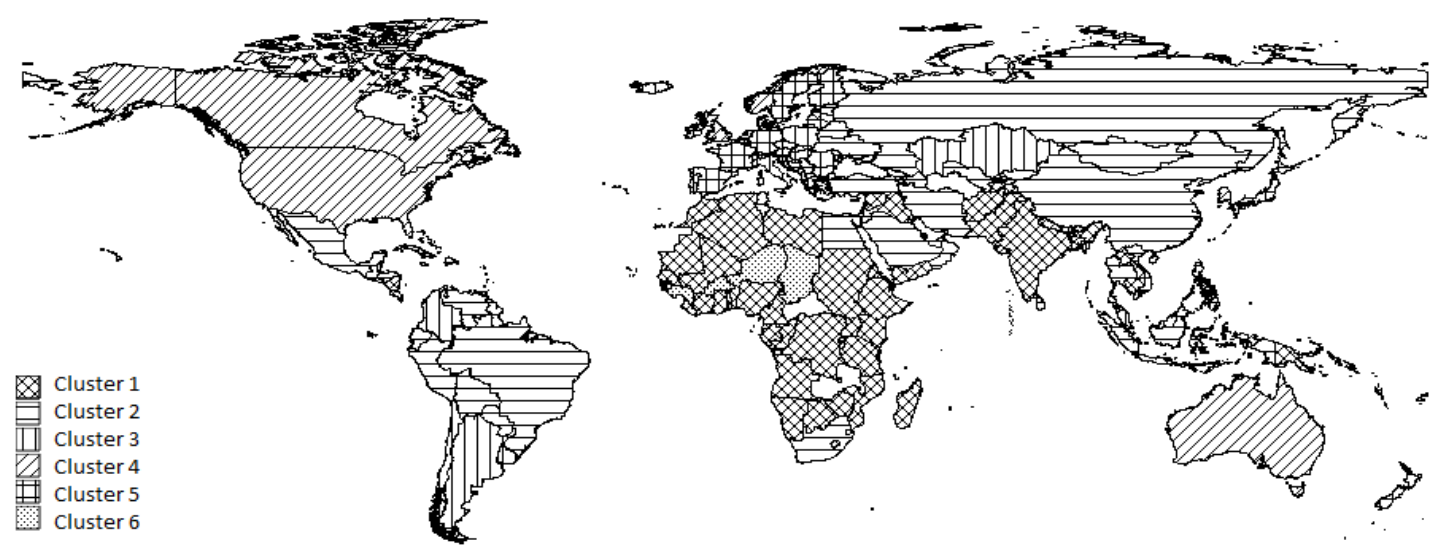

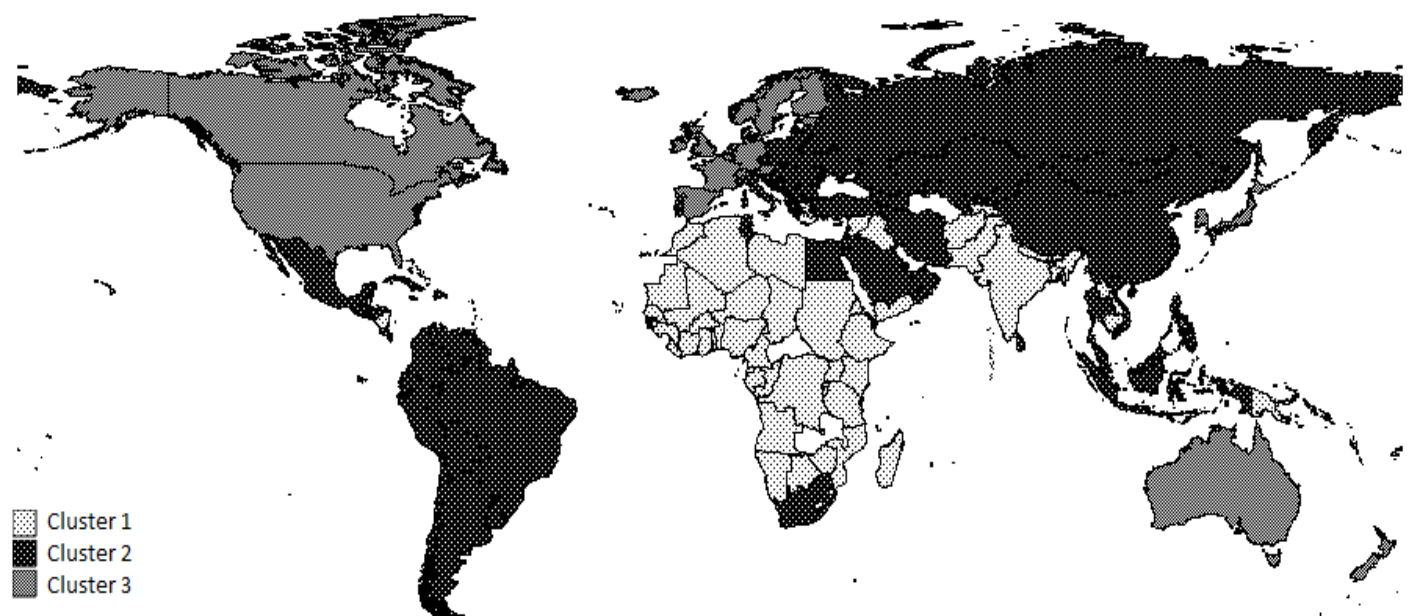

Fig. 2. States division in three clusters

If the distance measures between two clusters willdiscontinuous increase, the process of consolidating the new clusters need to be stopped, otherwise they are already being integrated into clusters, which are located in relatively long distance from one another. On the optimal is considered number of clusters, which are equal to the difference between the amount of observations (here 173) and the number of steps, after which the rate discontinuous increases (here 170). This means that after three cluster formation no longer need to carry out any further mergers and the outcome of the three clusters is the optimal result. The results were examined visually by three, four, five and six clusters and determined each state belonging of cluster.

Through statistical and cluster analysis, it was concluded that the best way is to use a three-cluster distribution (Fig. 2.).

\section{RESULTS}

After the cluster distribution, Latvia was ranked in second cluster. Latvian e-government development index (EGDI) is 0.5826, which indicates that we have quite a distance from the third cluster. The first cluster EGDI average value is 0.2661 , the second cluster average value is 0.4926 , while the third cluster average value is 0.7435 (TABLE 1 ).

EGDI consists of three indexes - the online service index (TPI), the telecommunication infrastructure index (TII) and the human capital index (CKI).

Analyzing TPI, the conclusion is that Latvia is far from the third cluster, because Latvian TPI is 0.4159. The second cluster average TPI is 0.3288 , while the third clusters have an average TPI 0.6388 (TABLE 1 ).

\section{TABLE 1}

E-GOVERNMENT DEVELOPMENT INDEX AND THE FACTORS AFFECTING THE AVERAGE VALUES OF THE THREE CLUSTERS

\begin{tabular}{|l|c|c|c|c|}
\hline & Latvia & Cluster 1 & Cluster 2 & Cluster 3 \\
\hline EGDI & 0,5826 & 0,2660 & 0,4926 & 0,7435 \\
\hline TPI & 0,4159 & 0,1331 & 0,3288 & 0,6388 \\
\hline
\end{tabular}

\begin{tabular}{|l|l|l|l|l|}
\hline TII & 0,3761 & 0,0544 & 0,2669 & 0,6293 \\
\hline CKI & 0,9608 & 0,6147 & 0,8872 & 0,9655 \\
\hline
\end{tabular}

The telecommunication infrastructure indexis the second component of EGDI is.

For Latvia this index is 0.3761 . In this field, Latvia has a long way from the third cluster, whose average value is 0,6293 , while the second cluster average value is 0.266953 (TABLE 1).

As third component of EGDI is the human capital index, Latvia is 0.9608 . With this assessment, Latvia is very close to the third cluster, which can be inferred from the third cluster average of 0.9655 . The second cluster average value is 0.8872 (TABLE 1).

Analyzing EGDI affecting factors impact on clusters can be concluded that TPI scattering by clusters is quite large, but its impact on all clusters are equal (Fig. 3.).

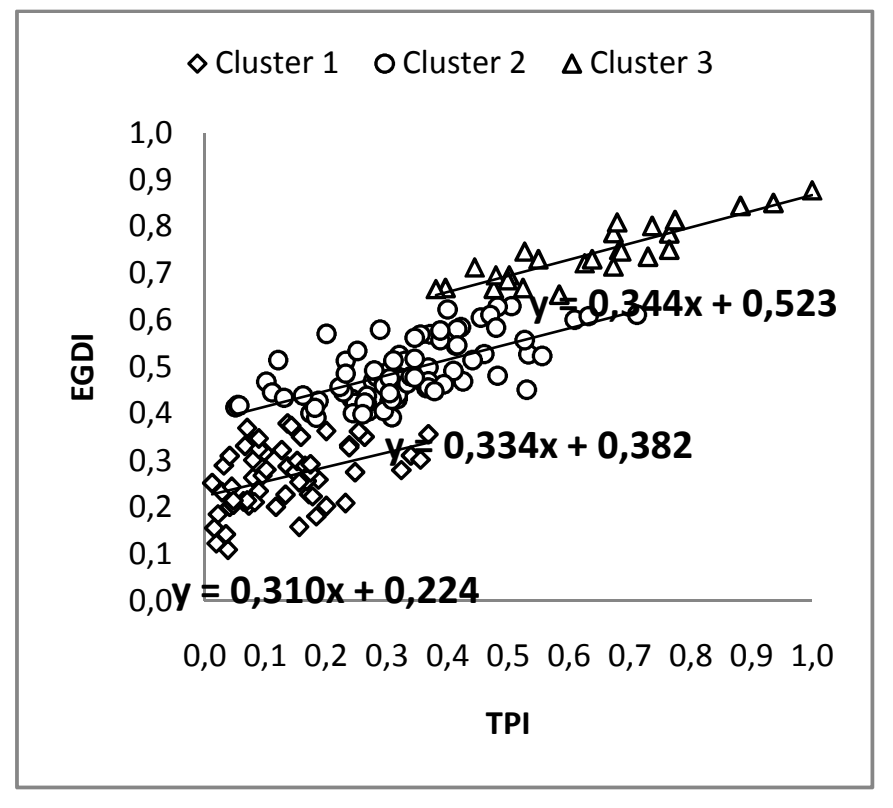


Fig. 3. The relationship between TPI and EGDI depending on the country cluster

To arrive at a set of online service index (TPI) values, the research team[3] assessed each country's national website as well as the websites of the ministries of education, labour, social services, health and finance.

Associated portals and subsidiary websites were considered part and parcel of the parent sites and taken into consideration when assigning values to survey responses.

Among other things, the national sites were tested for a minimal level of Web content accessibility as described in the

Web Content Accessibility Guidelines of the World Wide Web Consortium[5].

The survey[3] has four sections corresponding to the four stages of e-government development. The first of these stages includes questions relating to attributes that would be considered typical of an emerging online presence, the second to an enhanced presence, the third to a transactional presence and the fourth to a connected presence. Almost all questions in the survey call for a binary response of yes or no, with "yes" given one point and "no" zero. Exceptions include a small number of questions designed to capture data on the number of forms and e-services available. These are worth up to ten points each.

The telecommunication infrastructure index is a composite of five indicators: number of personal computers per 100 persons, number of Internet users per 100 persons, number of telephone lines per 100 persons, number of mobile cellular subscriptions per 100 persons and number of fixed broadbandsubscribers per 100 persons. The International Telecommunication Union was the primary source of data in each case.

Assessing the TII dependence from clusters follows that the dispersion in first cluster is low (Fig. 4.).

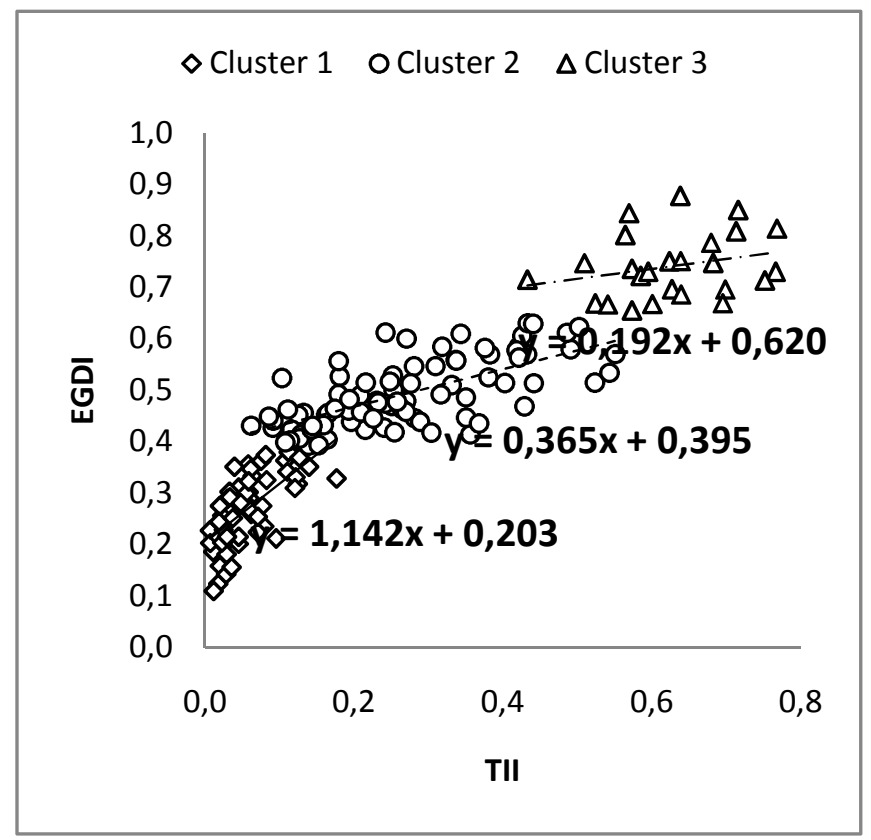

Fig. 4. The relationship between TII and EGDI depending on the country cluster

The human capital index is a composite of two indicators: adult literacy rate and the combined primary, secondary, and tertiary gross enrolment ratio. The United Nations Educational, Scientific and Cultural Organization were the main source of data in both cases.

Gaps were completed to the extent possible using data from the 2009 UNDP Human Development Report[6].

CKI impact on EGDI is essential, but its significance in clusters varies (Fig. 5.).

Reliable and relevant e-government measurement can offer crucial signposts to point policy makers and practitioners in the right direction. Some important common threads include a country's economic strength, technological development and aggregate level of education. All three of these factors pertain to capacity, and two of them - technology and education - are combined with a direct assessment of the state of national online services to produce the United Nations e-government development index.

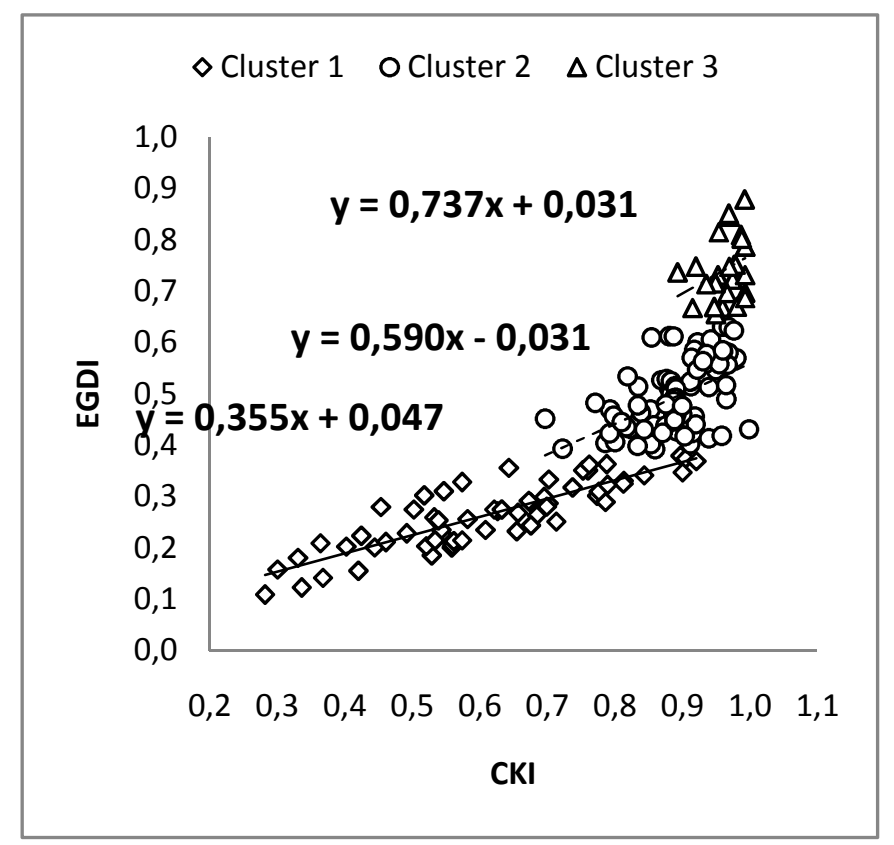

Fig. 5. The relationship between CKI and EGDI depending on the country cluster

Analyzing the situation described above, it can be concluded that EGDI should be analyzed separately for clusters and EGDI affecting factors, because the possible index increase is the variety of trends, so it is impossible to develop the same recommendations. EGDI three factors significance according from clusters was analyzedassessing the above results.

Evaluating the TPI, TII, and CKI significance on the EGDI depending from the cluster in result of regression analysis, were obtained the significance data of impact factors.

If the e-government development index influencing factor TPI increases by one unit, then EGDI increases by 0.311 in the 
first cluster, in second cluster by 0.335 and by 0.345 in the third cluster (Fig. 3.). Analyzing the data shows that the TPI effect is not independent of the clusters, because their effects weight on EGDI increase is equal to the leverage effect.

If the e-government development index influencing factor TII increases by one unit, then EGDI increases by 1.142 in the first cluster, in second cluster by 0.366 and by 0.303 in the third cluster(Fig. 4.). In all three clusters, the influencing factor is significant, but in the first cluster the TII impact on EGDI is with the greatest weight.

If the e-government development index influencing factor CKI increases by one unit, then EGDI increases by 0.355 in the first cluster, in the second cluster by 0.591 and by 0.738 in the third cluster (Fig. 5.). Consequently, it can be concluded that the effect of CKI in the second cluster is more important than in the first and third cluster.

\section{DISCUSSION}

The EGDI affecting factors TPI relevance is equally important for all clusters, because it is with almost equal impact weight on the EGDI depending on the clusters. Online services are relatively equally available to all countries[7].

The EGDI influencing factor TII is significantfor all clusters, but greatest impact is in the first cluster, because this cluster is based on the less developed countries where it is necessary to develop the telecommunications infrastructure in order to successfully develop other EGDI influencing factors increasing in the first cluster.

TII and TPI increase in Latvia case should be developed in the same level, because their impacts on EGDI have a similar impact weight. In Latvia case the CKI should not be developed in short-term, because it does not have significant impact on EGDI.

In the third cluster increasing the CKI is not significantly, because there are mainly the developed countries in high technology field. CKI as a whole is significant in first and second clusters. CKI factor on EGDI second cluster is greater than twice in the first cluster, because in the second cluster are located countries with already developed infrastructure and has an important base of human resource development. By contrast, the first cluster CKI factor influence relatively low proportion is explained by the fact that the first cluster countries are with poor infrastructure development, which is the precondition for EGDI affecting factors increasing.

Considering that significance of the different EGDI factors depends from the specific cluster and also from other influencing factors of these indicators, a more detailed analysis of the TPI, TII and CKI influencing performance would be required. TPI consists of four components - the estimated amount of points for new information services (JIPP), the calculated points for improved information services (UIPP), the calculated points of business services (DPP) and the calculated points of connected approach (SPP). TII affecting estimated components are a number of Internet users per 100 inhabitants (ILI), the main fixed telephone lines (TLI), a mobile telephone subscribers per 100 inhabitants (MAI), personal computers per 100 inhabitants (PDI) and the total fixed broadband per 100 inhabitants (FPI). Human capital index (CKI), which is EGDI third component involves the adult literacy rate (PLI) and the combined gross enrolment rate for primary, secondary and higher education schools (KII), which are expressed as a percentage.[3], [8], [9]

Analyzing the three EGDI influencing key factors (TPI, TII, and $\mathrm{CKI}$ ) is required to focus on those factors influencing rate dependence from the cluster.

That kind of analysis would be needed to effectively determine the influence of the effectiveness of EGDI and provide recommendations for further implementation of egovernment implementation of risk reduction.

Further e-service development and usage increasing will positively benefit the public administration process of development, as well as reducing bureaucracy, thereby saving time and human labour resources, as well as material resources.

Efficiency involves the reduction of service time, which includes client and service provider resources, and service cost reduction.

\section{CONCLUSION}

Latvia is in the second cluster group. The regression analysis for the second cluster group shows that it is important to increase value of CKI. However, the Latvian CKI value already is 0.9608 what is on par with values in the third cluster, and CKI is not the main barrier for entering the third cluster.

Latvia should develop TII, because the Latvian index is two times lower than in the average TII score in thethird cluster.

Latvia needs to develop the TPI, because the Latvian index for this factor is about one and half times lower than average TPI in developed countries.

Since Latvia's TPI and TII impact factor is approximately the same proportion, Latvia have to choose which of these two factors give priority to further their development. It is important to take into account these factors economic benefits, assessing the lower potential costs. For this purpose it is necessary to consider the next level EGDI factors affecting the significance of the TPI, TII, and CKI.

\section{REFERENCES}

[1] Andersen, K.V.,Henriksen, H.Z., "The First Leg of E-government Research: Domain and Application Areas 1998- 2003". International Journal of Electronic Government Research, 1(4), pp. 26-44, 2005

[2] Millard, J. Danish Technological Institute "ePublic services in Europe: past, present and future", Research findings and new challenges, Final Paper, 2003

[3] Department of Economic and Social Affairs, "United Nations EGovernment Survey 2010", Leveraging e-government at a time of financial and economic crisis, United Nations publication, United Nations, New York, 126.p., 2010

[4] MacKay, D."Chapter 20. An Example Inference Task: Clustering". Information Theory, Inference and Learning Algorithms. Cambridge University Press, 2003. pp. 284-292

[5] Caldwell, B.,Cooper, M.,Guarino Reid, L., Vanderheiden,G. "Web Content Accessibility Guidelines (WCAG) 2.0", W3C, 2008. [Online]. Available: http://www.w3.org/TR/2008/REC-WCAG20-20081211/. [Accessed: Mai. 15, 2009] 
[6] UNDP (United Nations Development Programme), Human Development Report 2009, Published for the United Nations Development Programme New York,229.p., 2009

[7] Economist Intelligence Unit,"E-Readiness Rankings 2009:the Usage Imperative". A report from the Economist Intelligence Unit, The Economist Intelligence Unit Ltd., 29p., 2009

[8] International Telecommunication Union, Measuring the Information Society: The ICT Development Index. Geneva: ITU, 108.p., 2009

[9] United Nations, Core ICT Indicators, Partnership on Measuring ICT for Development, UN-ESCWA, Berut, 53.p., 2005

Daiga Dumpereceived her Mg.sc.ing. in the Latvia University of Agriculture in 2006 .

\section{Daiga Dumpe, Irina Arhipova. Latvijas e-pārvaldes efektivitātes analīze}

Pētījumā analizēts E-pārvaldes atț̄istības indekss (EGDI). Šs indekss ir visaptveroša vērtēšana par valsts pārvaldes gatavību un spējām izmantot tiešsaistes un mobilo sakaru tehnolog̣ijas valdības funkciju izpildē. Papildus izvērtēts e-pārvaldes gatavības indeksa ietekmējošo faktoru būtiskums paaugstināšanai atkarībā no valsts, kā arī izvērtēts faktoru ietekmes īpatsvars e-pārvaldes gatavības indeksa paaugstināšanai Latvijas gadījumā. Veicot statistisko un klasteru analīzi, dati tika sadalīti trijos, četros, piecos un sešos klasteros, lai, izvērtējot rezultātus, tiktu izvēlēts optimālākais sadalījums. Tika secināts, ka visoptimālāk ir izmantot triju klasteru sadalījumu. Pēc klasteru iedalījuma Latvija ierindojās otrajā klasterī. Latvijas EGDI norāda uz to, ka esam diezgan lielā attālumā no trešā klastera.Regresijas analīzes rezultātā, izvērtējot TPI (tiešsaistes pakalpojumu indeksa), TII (telekomunikāciju infrastruktūras indeksa) un CKI(cilvēku kapitāla indeksa)būtiskumu uz EGDI atkarībā no klastera, tika iegūti ietekmējošo faktoru būtiskuma dati. Datu analīzes rezultātā iegūts, ka EGDI ietekmējošā faktora TPI būtiskums ir vienlīdz svarīgs visiem klasteriem, jo tas ir ar gandrīz vienādu ietekmes svaru uz EGDI atkarī̄ā no klasteriem. EGDI ietekmējošais faktors TII ir būtisks visiem klasteriem, bet vislielākā ietekme ir pirmajā klasterī. Izvērtējot iegūtos datus un veicot to analīzi, ir secināts, ka trešajā klasterī palielināt CKI nebūtu būtiski, jo tajā lielākoties atrodas attīstītās valstis augsto tehnologijiju jomā. CKI kopumā ir būtisks pirmajam un otrajam klasterim. N̦emot vērā, ka EGDI dažādu faktoru ietekmes būtiskums ir atkarīgs no konkrēta klastera un arī no citiem šo faktoru ietekmējošiem rādītājiem, būtu nepieciešams detalizētāk izanalizēt TPI,TII un CKI ietekmējošos rādītājus. Šāda analīze būtu nepieciešama, lai efektīiāā noteiktu faktoru ietekmes efektivitāti uz EGDI un sniegtu rekomendācijas turpmākai e-pārvaldes īstenošanas ieviešanas risku samazināšanai. Tā kā Latvijas TPI un TII ietekmes faktoru īpatsvars ir aptuveni vienāds, tad ir jāizvēlas, kuram no šiem abiem faktoriem dot priekšroku turpmākai to attīstībai. Svarīgi ṇemt vērā šo faktoru ekonomisko izdevīgumu, izvērtējot zemākās potenciālās izmaksas.

\section{Дайга Думпэ, Ирина Архипова. Анализ эффективности Латвийского э-управления}

В исследовании проведен анализ индекса развития э-управления (EGDI), который является общим показателем готовности государственного управления к возможностям использования оперативных и мобильных технологий связи при реализациисвоих функций. Дополнительно исследована значимость факторов, влияющих на возможностьувеличения индекса э-управленияв зависимости от государства, а так же оценен удельный вес тех факторов, которые влияют на увеличение индекса э-управления в Латвии.

При проведении статистического и кластерного анализа, данные были разделены на три, четыре, пять и шесть кластеров, чтобы при оценке результатов выбрать наиболее оптимальное решение. Был сделан вывод, что наиболее оптимально использовать разделение на три кластера. По результатам кластерного анализа Латвия принадлежит второму кластеру. Латвийский индекс EGDI указывает на то, что мы находимся на достаточно далеком расстоянии от третьего кластера. В результате регрессионного анализа, оценив значимость влияния индекса прямых услуг (TPI), индекса телекоммуникационных структур (TII) и индекса человеческих ресурсов (CKI) на EGDI в зависимости от кластера, были получены данные наиболее существенных факторов значимости. В результате анализа данных, выявлено, что значимость TPI на EGDI одинакова для всех кластеров, поскольку он имеет практически одинаковую степень влияния на EGDI независимо от кластера. Фактор TII значим для всех факторов, но наиболее весомое влияние он имеет в первом кластере. При оценке полученных данных, выявлено, что в третьем кластере увеличение CKI не столь важно, поскольку в нем находятся государства развитые в сфере высоких технологий. СКІ в общем итоге имеет значимость для первого и второго кластеров.

Принимая во внимание, что влияние различных факторов на EGDI находится в зависимости от конкретного кластера, а так же от других показателей влияния данных факторов, было бы необходимо более детально проанализировать факторы воздействия TPI, TII и CKI. Tакой анализ необходим, чтобы более точно определить эффективность влияния факторов на EGDI и дать рекомендации для уменьшения рисков при дальнейшем введении эуправления.

Поскольку для Латвии степень влияния ТРІ и ТІІ примерно одинакова, нужно решить, какому из факторов отдать предпочтение в дальнейшем его развитии. Необходимо принимать во внимание экономическую выгоду от данных факторов, оценив наиболее низкие потенциальные затраты. 